\title{
Tobacco Control in Industrialized Nations: The Limits of Public Health Achievement
}

\author{
Ronald Bayer, $\mathrm{PhD},{ }^{1}$ \\ Eric Feldman, PhD, JD ${ }^{2}$
}

\begin{abstract}
In 1999 Gro Harlem Brundtland, Director General of the World Health Organization, painted a stark picture of the global toll in morbidity and mortality that could be expected from tobacco consumption. "Tobacco-related diseases are spreading like an epidemic and are likely to be killing ten million people a year around 2020." The warning was coterminous with the drafting by the WHO of the Framework Convention on Tobacco Control, a treaty designed to interrupt and reverse the "epidemic's" course. In the next decades attention to the impact of tobacco will shift to the less developed and rapidly modernizing nation. At this juncture it would be useful to review the almost half-century long public health campaign to confront tobacco in the industrialized nations, where extraordinary achievements in the reduction of tobacco consumption reflect the impacts of persistent public health efforts in the face of powerful commercial resistance.

The five countries we have focused on here France, Germany, Japan, the United Kingdom and the United States share a broad commitment to liberal political values yet they differ in important ways. Two are common law and two are civil law states. Japan is a "mixed" system; The US and Germany are federal systems. France, the United Kingdom and Japan are unitary. Yet despite these differences and those that characterized their first encounters with tobacco they now reflect a broad convergence on the most effective public policy responses to smoking related morbidity and mortality. The experiences and differences of these nations is important to note even though to some careful observers of the global politics of tobacco none would have been classed as pioneers in tobacco control.

This analysis is drawn from a broader examination of the global picture of tobacco control at the end of the first decade of the $21^{\text {st }}$ century. ${ }^{2}$
\end{abstract}

\footnotetext{
${ }^{1}$ Center for the History and Ethics of Public Health, Co-Chair and Professor, Mailman School of Public Health, Columbia University, New York, NY, USA

${ }^{2}$ Deputy Dean for International Affairs and Professor of Law, University of Pennsylvania Law School, Philadelphia, PA, USA
}

Corresponding Author Contact Information: Ronald Bayer, Center for the History and Ethics of Public Health, Mailman School of Public Health, Columbia University, New York, NY, USA 
Keywords: Tobacco Control, public health, tobacco legislation

Recommended Citation: Bayer R, Feldman E. Tobacco Control in Industrialized Nations: The Limits of Public Health Achievement. Public Health Reviews. 2012;33:553-68.

\section{INTRODUCTION}

In the first half of the $20^{\text {th }}$ century, tobacco consumption rapidly escalated in the world's industrializing nations. Almost as quickly, with the emergence in midcentury of a scientific consensus that cigarette smoking posed a profound threat to the health of individuals and societies, there began an extraordinary movement to limit, control, and ultimately eliminate tobacco use. What started as a campaign fueled by public health advocates and resisted by private and public actors dependent upon tobacco revenues had, by century's end, triggered far-reaching social, political, and economic changes in the United States and Western Europe. Although, as we shall see, there are some striking differences between 1963 and 2002, the prevalence of smoking among men in the West was reduced by 50 percent; among women there were also significant if less dramatic achievements. Table 1 underscores the magnitude of the changes.

Table 1

Changes in prevalence of smoking among men and women between 1963-1965 and 2002

\begin{tabular}{l|c|c|c|c}
\hline \multirow{2}{*}{} & \multicolumn{2}{|c|}{ Men } & \multicolumn{2}{c}{ Women } \\
\cline { 2 - 5 } & $\mathbf{1 9 6 3 - 1 9 6 5}$ & $\mathbf{2 0 0 2}$ & $\mathbf{1 9 6 3 - 1 9 6 5}$ & $\mathbf{2 0 0 2}$ \\
\hline France & $72 \%$ & $33 \%$ & $33 \%$ & $21 \%$ \\
\hline Germany & $61 \%$ & $39 \%$ & $31 \%$ & $24 \%$ \\
\hline United Kingdom & $83 \%$ & $57 \%$ & $16 \%$ & $16.6 \%$ \\
\hline United States & $52 \%$ & $28 \%$ & $43 \%$ & $26 \%$ \\
\hline
\end{tabular}

Source: Feldman and Bayer 2004 ${ }^{40(\mathrm{p} .300)}$; Fukuda et al. 2005. ${ }^{4}$

For much of the postwar era, the rates of smoking among Japanese men were almost twice that of other developed nations. In 1965, 83.2 percent of men smoked, and in 199757.6 percent were still smokers. ${ }^{3}$ Among women, there was virtually no change in that same 20 -year period. More striking, 
the steep social gradient in terms of income and education that characterizes smoking in Western Europe and the US was all but absent. Ten years later, in 2004, a study found virtually no change in smoking at the population level among men. When the analysis was stratified by age, however, the impact of income among those aged 25-39 was most obvious. Thus, although overall smoking rates remained high, "the impact of income on smoking was not much smaller than in other industrialized nations". ${ }^{4}$

What strategies and policies can account for the changes we have witnessed? Do they tell us anything about what may be necessary to advance the public health campaign against tobacco? As industrialized nations sought to confront both an industry that manufactured a toxic product and a deeply embedded pattern of social behavior, they pursued a common set of strategies. Among the first interventions was the requirement that cigarette packages and advertisements include warning labels. But warnings alone were quickly understood to be insufficient to counteract the impact of advertising. As a result, public health advocates began to press for limits or bans on the advertising and promotion of tobacco products. ${ }^{5}$

In addition to their focus on advertising restrictions, tobacco control advocates have also pressed for price-based regulations. Tobacco has long been the object of taxation, and tobacco taxes have represented an important source of government revenue. By the 1980s, some economists began to argue that certain costs of smoking, such as health care expenditures and lost productivity, represented negative externalities. ${ }^{6}$ Those costs could be internalized, they claimed, through the imposition of taxes. Such justifications would assume less importance as public health officials increasingly asserted that the purpose of taxation was the suppression of demand. The extent to which the elasticity of demand was affected by the addictive nature of nicotine was a matter of some dispute, but the fact that prices could affect consumption, particularly by adolescents and others with limited disposable income, was beyond question. Whether such taxes are unacceptably regressive in light of the social gradient that has emerged or whether the increased burden on the relatively poor can be justified by the extent to which such burdens advance the health of those compelled to pay higher prices for cigarettes, remains controversial.

Finally, governments have moved to restrict smoking in public settings. Such moves often occurred before the evidence of harm to non-smokers was substantiated, ${ }^{7}$ but ultimately science provided a powerful warrant for such environmental measures. Although third-party harms remained central to the argument for extending restrictions on public smoking, it was clear to careful observers that an equally important goal was to affect the behavior of smokers themselves. 


\section{ADVERTISING}

Tobacco advertising had been the target of public health campaigns since the 1960s, but by the 1990s evidence clearly revealed that partial restrictions on advertising were ineffective because they resulted in the placement of promotional materials in unaffected media. France, in 1994, came early to the notion of a total ban on advertising. In the UK, the Tobacco Advertising Promotion Act of 2002 imposed a total prohibition on both advertising and the sponsorship of sporting events. Germany however, resisted this trend. Table 2 underscores this point.

Table 2

Legislation on direct advertising of tobacco products, 2006

\begin{tabular}{l|l|l|l|l}
\hline & $\begin{array}{c}\text { Television, } \\
\text { Cable, Video }\end{array}$ & $\begin{array}{c}\text { Locally Printed } \\
\text { Magazines and } \\
\text { Newspapers }\end{array}$ & Billboards & Cinema \\
\hline France & Ban & Ban & Ban & Ban \\
\hline Germany & Ban & No restrictions & No restrictions & Partial \\
\hline United Kingdom & Ban & Ban & Ban & Ban \\
\hline
\end{tabular}

Source: WHO Reg. Off. Eur. 2007. ${ }^{17}$

It is against this backdrop that the move by the European Union to ban all forms of tobacco advertising should be understood. In 2002, despite the opposition of Germany, the EU voted to prohibit advertising in magazines, in newspapers, on the Internet, and at international sports events. ${ }^{8}$ Three years later, the EU's Tobacco Advertising Directive went into effect, and the EU Commissioner for Health and Consumer Protection stated: "Banning tobacco advertising is one of the most effective ways of reducing smoking". In 2006, the European Court of Justice rejected Germany's challenge to the bans. Focused solely on the question of whether such regulations were a legitimate exercise of EU-wide authority, and not whether the issue of restrictions on advertising represented an intrusion on human rights, the Court stated that "the prohibitions of advertising and sponsorship meet the conditions for them to be adopted for the purpose of the establishment and functioning of the internal market". ${ }^{10}$

The situation in the US was dramatically different, with First Amendment jurisprudence providing a constitutional protection for advertising unparalleled in other industrial democracies. Building on its 
prior decisions protecting "commercial speech", the Supreme Court in 2001 ruled against an effort by Massachusetts to limit billboards that advertised cigarettes proximate to schools (Lorillard Tok Co. v. Reilly 2001). ${ }^{11}$ With this history in mind, the Food and Drug Administration (FDA) drafted new tobacco control legislation in 2009. The new regulations sought to prohibit outdoor advertising within 1,000 feet (300 meters) of schools and playgrounds, limit advertising to a simple block text on white background (the "tombstone" format) in publications with a significant youth readership, limit advertising in video to static black and white, and ban brand name sponsorships of sporting and cultural events (Family Smoking Prevention and Tobacco Control Act, 2009). ${ }^{12}$ The FDA's approach fell far short of the EU's effort to prohibit advertising in all print media, and indeed to some public health advocates was utterly inadequate (Why was 1000 feet toxic but not 1001 feet?) but it did not go unchallenged. The American Civil Liberties Union, questioning the constitutionality of the proposed regulations, stated that "regulating commercial speech for lawful products only because those products are widely disliked"-even for cause - was a dangerous precedent. "The antidote to harmful speech can be found in the wisdom of countervailing speech — not in the outright ban of the speech perceived as harmful." ${ }^{13}$

Similar civil liberties concerns do not explain the state of advertising restrictions in Japan, however. Although the Tobacco Enterprise Law of 1984 discouraged "excessive" advertising, it imposed no sanctions. Rather, the limited tobacco advertising in Japan is explained by the powerful influence of Japan's own tobacco industry, which did not favor spending money on advertising and indeed had much to fear from campaigns that might lure smokers to newly available American products. The first guidelines to restrict advertising were issued in 1989 and imposed limits on television and radio ads. ${ }^{14} \mathrm{~A}$ decade later, new regulations were issued banning ads on television, radio, and the Internet and in movie theaters. In addition, the rules discouraged advertising in publications that appealed to youth and women and banned billboards within 300 feet (90 meters) of schools. The ubiquitous posters on buses, subways, and trains remained untouched. In 2004, the Japanese government moved to impose more restrictive measures, banning ads on trains and buses. ${ }^{14}$ Strict limits were also placed on the frequency of newspaper advertisements, limiting them to 12 per year. Thus, legal restrictions on tobacco advertising in Japan are weaker than in many other industrialized nations, but they have been strengthened in recent years and, along with industry self-regulation, have contributed to an overall decline in tobacco advertising. 


\section{TAXES}

The move toward broad policy convergence among industrialized nations is also reflected in their shared recognition of the central role that taxes can play in reducing tobacco consumption. In 2010, experts from 12 nations met under the auspices of the International Agency for Research on Cancer to review and assess the evidence on tax and price policies in tobacco control. There was, asserted the group, "sufficient" evidence to conclude that there was a negative relationship between cigarette prices and cigarette consumption in countries at all levels of income. "Individual-level or household-level data corroborate an inverse relationship between cigarette price and total demand." ${ }^{15}$ Speaking to the issue of the social class dimensions of such taxation in industrialized nations, the expert group concluded that there was "strong" evidence that in high-income countries tobacco use among lower-income populations was more responsive to tax and price increases than was the case for higher-income populations. This important international review merely confirmed what was already under stood by public health officials in individual industrialized nations.

In Great Britain, the taxation of cigarettes for purposes of public health began in the 1970s, and thereafter there were annual tax increases. In the 1990s, the social class gradient and the incidence of taxation emerged as an issue for those concerned about equity. Nevertheless, the centrality of tax policy to reducing population-level tobacco use led in 1992 to the policy report The Health of the Nation, in which the government stated that it would raise the tax on cigarettes at least three percent per year to help reduce smoking. Tax rates continued to rise in the next years, in part because they were linked to inflation. In 2010, the activist group Action on Smoking and Health argued for yet another tax hike: "[When] tax accounts for over 75 per cent of the retail cost of a typical packet of cigarettes, is there justification for raising the tax level further? We believe there is" ${ }^{16(p .5)}$

In France, tobacco consumption increased throughout the 1980s, defying the pattern in the US and other economically advanced democracies, and remained stable in the early 1990s. There, the enactment of the muscular Evin Law in 1991, which contained prescribed tax increases, had a demonstrable impact on tobacco consumption. A WHO analysis of the relationship between price and tobacco consumption in France concluded that from 1993 to 2000 tax increases caused the price of cigarettes to go up annually by five percent. More dramatically, legislation in 2003 raised the price of cigarettes by 40 percent and caused sales to fall by 33.5 percent. ${ }^{17}$ The impact of such taxes was not lost on financial analysts. As Morgan Stanley reported, "Of the various measures available to governments in 
reducing demand for tobacco, clearly the one that concerns the cigarette companies the most is rising taxation". ${ }^{1(p .14)}$

The situation has been different in Germany, where resistance to strict tobacco control measures has long been a characteristic of public policy. At the start of the $21^{\text {st }}$ century, one analyst concluded that "Germany still ranks among the few European countries that have abstained from dramatic [tax] increases". ${ }^{19}$ However, beginning in 2001, there were five annual tax increases on cigarettes, with the net result of a 33 percent rise in the real price of cigarettes. ${ }^{20}$ Then, in 2010, the German government announced an increase of the tobacco tax. But on this occasion, the measure was clearly designed to enhance revenues to compensate for expected financial loses that would be incurred as a result of tax relief measures for the energy industry, which would lead to a revenue shortfall without higher taxes in other sectors.

In the US, where pressing for tobacco tax increases had long been a central strategy of public health officials and activists, the financial crisis of 2008 drove states to increase cigarette taxes as a way of confronting fiscal concerns. Whatever the motivation, such levies were welcomed by those committed to reducing tobacco consumption. Because excise taxes on cigarettes are largely a matter of state and local policy, vast discrepancies characterize how effectively price has been used as a strategy for reducing consumption. ${ }^{21}$ In 2010, New York State's tax of $\$ 4.20$ per pack led the nation. Four additional states had taxes above $\$ 3.00$. Twenty-one states, however, taxed cigarettes at less than $\$ 1.00$, and Missouri imposed a tax of only 17 cents. The extensive empirical evidence on the impact of tax increases (and consequent price increases) on overall cigarette consumption provided the foundation for those who continued to press for higher taxes and who decried the existence of states that failed to employ such a policy lever. For the American Lung Association, which lamented the failure to use cigarette tax revenues to fund smoking cessation programs, the answer to the question, "What is the appropriate level to tax cigarettes to protect public health?" is simple: "The higher the better". ${ }^{21(p .35)}$

There were, however, some dissenting voices in the tobacco control community. Given the social gradient of tobacco consumption in the US, there was concern about the burden of higher taxes on the relatively poor, who could not or would not give up cigarettes. Others were troubled by the neo-prohibitionist implications of ever higher taxes. At stake was the fundamental question of how and under what circumstances the claims of public health could justify limitations of the self-regarding harmful behavior of adults. Robert Rabin, who for years oversaw the Robert Wood Johnson Foundation's work on tobacco and drug policy, expressed the concern pointedly. "Why not a de facto ban through aggressive use of the excise tax? 
As a practical concern, a smoking ban carries all of the attendant risks of smuggling and other illegal forms of access. The historical experience in the Prohibition Era has left an indelible imprint on American political thought. But more fundamentally; an outright ban raises the ethical issue of whether the state should engage in such a proactive course of paternalism."22

Japan, where smoking rates among men were higher than in other industrialized nations and where Japan Tobacco's intimate involvement with the state (the government owns 50\%) has left an indelible mark on the politics of cigarette consumption, came late to the explicit use of tax policy to confront the challenge of tobacco consumption. Nevertheless, even there the global trend toward using tax policy to curb smoking was evidenced in 2010. In supporting a tax increase that would raise the price of cigarettes by 30 percent, the Ministry of Health declared that "tobacco poses health problems. It may be necessary to raise [the tax] to the levels of Europe." ${ }^{\prime 2}$ "We hope the price increase will discourage smokers from buying cigarettes and eventually help them quit smoking." 24

\section{LIMITS ON PUBLIC SMOKING}

Restrictions on smoking in public settings were slow to take hold in Europe, despite the efforts of tobacco control advocates who centered their arguments on the negative health consequences for nonsmokers. The WHO's regional office for Europe noted that by 2001 no member state had achieved the goal of "eliminating involuntary exposure to tobacco smoke in all public places." ${ }^{25}$ Table 3 makes clear how limited progress had been in France, Germany, and the United Kingdom.

Table 3

Limits on public smoking in France, Germany, and the UK, 2001

\begin{tabular}{l|l|l|l|l|l}
\hline & $\begin{array}{c}\text { Health-care } \\
\text { Settings }\end{array}$ & $\begin{array}{l}\text { Government } \\
\text { Facilities }\end{array}$ & Restaurants & $\begin{array}{c}\text { Bars and } \\
\text { Pubs }\end{array}$ & $\begin{array}{c}\text { Indoor } \\
\text { Work } \\
\text { Places }\end{array}$ \\
\hline France & Partial & Partial & Partial & Partial & Partial \\
\hline Germany & $\begin{array}{l}\text { No } \\
\text { restrictions }\end{array}$ & $\begin{array}{l}\text { No } \\
\text { restrictions }\end{array}$ & $\begin{array}{l}\text { No } \\
\text { restrictions }\end{array}$ & $\begin{array}{l}\text { No } \\
\text { restrictions }\end{array}$ & $\begin{array}{l}\text { No } \\
\text { restrictions }\end{array}$ \\
\hline $\begin{array}{l}\text { United } \\
\text { Kingdom }\end{array}$ & $\begin{array}{l}\text { No } \\
\text { restrictions }\end{array}$ & $\begin{array}{l}\text { No } \\
\text { restrictions }\end{array}$ & Voluntary & Voluntary & $\begin{array}{l}\text { No } \\
\text { restrictions }\end{array}$ \\
\hline
\end{tabular}

Source: WHO Reg. Off. Eur. 2002. ${ }^{25}$ 
During the next decade, extensive changes would occur. Commenting on this transformation, The Lancet in 2007 noted: "Europe is finally stumbling out from under its centuries-old haze of cigarette smoke, as nations that have traditionally clung to their favorite vice" began to follow the examples set by Wales, Ireland, Scotland, Malta, Italy, and Sweden. ${ }^{26(p .}$ 1507) As of mid-2007, smoking bans went into effect throughout the UK. France, which had introduced some of the first public smoking restrictions in Europe in 1992, moved in 2007 to impose new restrictions, this time with a very different commitment to enforcement. In 2009, those bans were extended to restaurants and bars. ${ }^{27}$

In 2006, the complex federal politics of Germany, as well as the influence of the tobacco industry, thwarted initial efforts by Chancellor Angela Merkel to impose the kind of restrictions that had begun to characterize public spaces in other EU settings. Instead, Berlin imposed bans in federal government buildings, on trains, and in train stations, and the 16 Länder were left to determine their own regulations. Bavaria took the lead. In a 2010 popular referendum, 60 percent of voters endorsed a ban on smoking in all clubs, bars, restaurants, cafes, and "beer tents". The new restrictions, vehemently opposed by bar owners and restaurant associations, extended restrictions first imposed in 2008.

Indicative of the changed political and cultural climate surrounding smoking in Europe, the European Commission's top health official declared in October 2010 that he would press for EU-wide restrictions, stating that "we need a complete ban on smoking in all public spaces, transport and the workplace". ${ }^{28}$

In the US, despite the passage of the Family Smoking Prevention and Tobacco Control Act and the FDA's new tobacco control mandate, regulating public smoking remains the prerogative of states and localities. As a consequence, limitations vary widely. The American Lung Association's 2010 Annual Report, State of Tobacco Control, presents a stark picture. In a grading system based exclusively on the regulation of public smoking, 22 states were given an "A" rating, including the entire West Coast, New England (with the exception of New Hampshire), New York, and New Jersey; eight were given a "B" rating; and 12 states received an "F" rating. ${ }^{21}$ According to the American Nonsmoker's Rights Foundation, in 2011 almost 80 percent of the US population lived in locales that banned smoking in workplaces and/or restaurants and/or bars; approximately 50 percent lived in areas that banned smoking in all workplaces, restaurants, and bars. ${ }^{29}$ 
Notably, although the American Lung Association expressed concern about what it characterized as "drastically" slow passage of comprehensive smoke-free laws, striking evidence revealed an increasing receptivity among public health advocates to ever more restrictive measures. Steven Schroeder (former president of the Robert Wood Johnson Foundation) and Kenneth Warner (former dean of the School of Public Health at the University of Michigan), for example, have noted approvingly the prospect of extending smoke-free laws to automobiles where children are present, residential apartments and condominiums, and public parks and beaches. ${ }^{30}$ Indeed, in 2010 New York's City Council passed legislation proposed by the Commissioner of Health to prohibit smoking on all beaches, in all parks, and in all pedestrian malls, and there was little sign of public opposition to these restrictions. In so doing, New York joined more than 500 other communities that had already taken some steps to bar smoking in outdoor settings. ${ }^{31}$

The picture looks very different in Japan, which among industrialized nations remains the least receptive to imposing extensive restrictions on smoking in public settings. But even Japan has experienced changes. In 2003, the country's most significant tobacco control legislation, the Health Prevention Law, went into effect. Despite its weak wording, it has spurred a wide range of actions. Ten private railway companies in the Tokyo Metropolitan area, for example, banned smoking in all their stations. West Japan Railway, a major carrier, banned smoking at all of its 1,200 stations. ${ }^{14(\mathrm{p} .778)}$ In 2006, 60 municipalities-whose residents constitute ten percent of Japan's population-had some form of tobacco regulation, including in some cases prohibitions on smoking on sidewalks. However, only in 2010 did the Ministry of Health propose regulations requiring local governments to ban smoking in schools, hospitals, offices, and buses, but it continued to allow restaurants, bars, and hotels to maintain smoking areas. Kanagawa, Japan's second largest (of 47) prefecture, with nine million residents, enacted a statute in 2010 that largely mirrored the Health Minister's proposals. ${ }^{32}$

\section{DENORMALIZATION}

Each of these policy strategies_-bans on advertising, increasingly steep excise taxes, and ever more restrictive measures regarding public smokingcontributed to a drop in smoking prevalence. It would be a mistake, however, to examine each policy in isolation and not observe their cumulative and synergistic impacts. Perhaps most striking has been how 
the increasingly restrictive policy context has both drawn upon and contributed to the transformation of social norms surrounding smoking. As social historian Allan Brandt put it, during the latter part of the twentieth century, the "aroma" of smoke had become a "stink". ${ }^{33}$ The process of denormalizing smoking was, at first, the consequence of the public health interventions discussed above. But as evidence began to accumulate about how denormalization itself could have a significant impact on the prevalence of smoking, a striking change occurred. Tobacco control advocates and public policy makers began to explicitly pursue denormalization, seeing it not simply as a desirable consequence of other policy interventions but as a discrete policy goal, one that could in turn provide the social context for ever more restrictive measures.

In the US, for example, the Massachusetts tobacco control program thus noted, "norms that allow smokers to smoke in most venues, including while at work or home, provide little incentive to quit". ${ }^{34(\mathrm{pp} .79-80)}$ Florida's tobacco control efforts sought to "deglamorize" smoking, and the extent to which students were "less likely to buy into the allure of tobacco" was reviewed as a mark of their efforts' impact " ${ }^{35}$ California's campaign to "denormalize" tobacco consumption sought "to push tobacco use out of the charmed circle of normal desirable practice to being an abnormal practice". ${ }^{36}$ Lauding the efforts of the California Health Department, Gilpin et al. embraced the force of social conformity, noting, "In a society where smoking is not viewed as an acceptable activity, fewer people will smoke, and as fewer people smoke, smoking will become ever more marginalized." $37(\mathrm{p} .38)$

In Europe as well, the utility of denormalization has been embraced. In 2007, a report from the Directorate General of Health and Consumer Protection of the European Commission titled "Towards a Europe Free from Tobacco Smoke" noted that among the benefits of restrictions and limits on public smoking was that "they contributed to the denormalization of smoking within society". ${ }^{38(p p .8,24)}$ That broad transformation would, according to the report, contribute to facilitating quitting by smokers and discourage children and adolescents from beginning to smoke.

By 2010, the process of denormalization had become so important to those committed to advancing the public health agenda on tobacco smoking that the editor of Tobacco Control, the leading international academic research and policy journal, argued that "score card" accounts of progress on tobacco control should be complemented with data on the "diverse ways that the positive culture of smoking has been eroded". ${ }^{39(\mathrm{p} .31)}$ 


\section{THE SOCIAL GRADIENT: A PRODUCT OF SUCCESS}

Public health interventions in advanced industrialized nations have produced remarkable changes at the population level as noted in the introduction to this paper. These striking achievements, however, fail to make clear the emergence of a steep social gradient in smoking that accompanied this transformation. With extraordinary rapidity, what had once promised to be a broadly democratic advance is increasingly inscribed by sharp class disparities. By 1974, the gradient in the US was already clear: 52 percent of men with no high school diploma smoked, but that was true for only 28 percent of those who had graduated from college. By 2000, the rate of smoking had declined to 36 percent among men with less than a high school education and to 11 percent among those with a bachelor's degree or higher. A similar pattern was found among women. Whereas 36 percent of less educated women smoked in 1970, 25 percent of those with university degrees smoked; 16 years later, the rates were 27 percent and ten percent, respectively. In Great Britain and France, the smoking rate at the end of the twentieth century was 2.3 times higher among men with low versus high educational attainment. For women in Great Britain, the differential was 2.5, and in France it was 1.4. ${ }^{40(\mathrm{p} .304)}$

What makes the social gradient of tobacco consumption, morbidity, and mortality in industrialized nations so striking is that it appears to have been created by public-health campaigns designed to limit tobacco consumption. There is abundant historical precedent. When previously uncontrollable diseases become subject to effective intervention or when the etiologic bases for disease is exposed and the prospect of intervention emerges, patterns of social inequality have long had a profound impact on who remains at risk. Jo Phelan and Bruce Link, whose work has strongly influenced the "fundamental cause" perspective on public health, underscore this point in their paradoxically titled paper, "Controlling Disease and Creating Disparities: A Fundamental Cause Perspective." As their research demonstrates, "[w]hen we develop the ability to control disease and death, the benefits of this new-found ability are distributed according to resources of knowledge, money, power, prestige, and beneficial social connections". ${ }^{41(\text {. } 27)}$ Such advantages, they have demonstrated, "shape individual health behaviors by influencing whether individuals are aware of, have access to, can afford, and are supported in their efforts to engage in health-enhancing behaviors". ${ }^{41(\text {. 22) }}$ 


\section{THE WAY FORWARD}

The current state of affairs with regard to adult smoking in developed nations that have already adopted muscular tobacco control programs poses a difficult ethical and policy challenge. In the US, smoking among adults stabilized between 2006 and 2008. In Europe, EU observers stated that "overall prevalence has reached a level from which it will be difficult to show further decline unless substantially stronger measures are implemented". ${ }^{17}$ For some, the data suggested that there was no alternative but to further tighten the public health vise. The goal of limiting tobaccorelated morbidity and mortality provided ample warrant for pressing on. Others were less certain. Rabin whose concerns about the potentially prohibitionist goals of ever higher taxes were noted earlier, ${ }^{22(p .1754)}$ has thus noted: "It is important to retain perspective on the fact that for some smoking is a pleasurable and/or psychologically rewarding experience. And correlatively, we should not lose perspective on the question of how restrictive a society we want to create-that is, how-far we want to go in reducing individual autonomy, including what can be perceived as selfdestructive behavior." The issues are especially complex because significant decreases in the prevalence of smoking at the population level can only be achieved if measures are targeted at those at the lower end of the social gradient. It is they who would, in the long term, benefit from reductions in cancer and cardiovascular disease. The question that remains is whether such benefits provide ample justification for class-inflected restrictive interventions in the near term.

Acronyms list:

FDA $=$ United States Food and Drug Administration

Conflicts of Interest: None declared.

\section{REFERENCES}

1. Brundtland GH. Why investing in global health is good politics, speech. Council on Foreign Relations. New York, NY; 6 December, 1999. Available from URL: http://www.who.int/director-general/speeches/1999/english/19991206 _new_york.html (Accessed 13 December, 2011).

2. Feldman EA, Bayer R. The triumph and tragedy of tobacco control: A tale of nine nations. Ann Rev Law Sci. 2011;7:79-100.

3. Honjo K, Kawachi I. Effects of market liberalization on smoking in Japan. Tob Control. 2009;9:193-200. 
4. Fukuda Y, Nakamura K, Takano T. Socioeconomic pattern of smoking in Japan: income inequality and gender and age differences. Ann Epidemiol. 2005; $15: 365-72$.

5. Board Trustees Am. Med. Assoc. Media advertising for tobacco products. JAMA. 1986;255:1033.

6. Hodgson TA. Cigarette smoking and lifetime medical expenditures. Milbank Q. 1992;70:81-125.

7. Takeshi H. Non-smoking wives of heavy smokers have a higher risk of lung cancer: a study from Japan. BMJ. 1981. 282:183-85.

8. BBC News. EU adopts tobacco ad ban. BBC News World Ed. 22 December, 2002. Available from URL: http://news.bbc.co.uk/2/hi/europe/2535071.stm (Accessed 13 December, 2011).

9. Associated Press. EU uncertain if all nations will comply with upcoming law banning some tobacco sponsorship. AP Worldstream. 27 July, 2005.

10. Newman M, Bodoni S. EU-wide tobacco ad ban upheld by European Union's highest court. Bloomberg News. 12 December, 2006. Available from URL: http://www.bloomberg.com/apps/news?pid=newsarchive \&sid=a3U5tTDAR API (Accessed 13 December, 2011).

11. Lorillard Tobacco Company, et al. v. Thomas F. Reilly, Attorney General of Massachusetts, et al.; Altadis U.S.A. Inc., etc., et al. v. Thomas F. Reilly, Attorney General of Massachusetts, et al. Supreme Court of the United States. Decision 28 June, 2001. 533 U.S. 525 (2001).

12. Family Smoking Prevention and Tobacco Control Act. United States. H.R. 1256. Public Law No: 111-31. Enacted 11 June 2009. Available from URL: http://thomas.loc.gov/cgi-bin/bdquery/z?d111:H.R.1256: (Accessed 13 December, 2011).

13. American Civil Liberties Union. ACLU to U.S. Senate, June 1, Re: ACLU Calls for Narrowing Advertising Restrictions in S. 982, The Family Smoking Prevention and Tobacco Control Act. ACLU. Washington, DC; 1 June, 2009. Available from URL: http://www.aclu.org/files/images/asset_upload_ file503_39723.pdf (Accessed 13 December, 2011).

14. Feldman EA. The culture of legal change: a case study of tobacco control in 21st century Japan. Mich J Int Law. 2006;27:743-822.

15. Chaloupka FJ, Straif K, Leon ME. Effectiveness of tax and price policies in tobacco control. Tob Control. 2010;20:235-8.

16. Reed $\mathrm{H}$. The effects of increasing tobacco taxation: a cost benefit and public finances analysis. ASH Rep., Action on Smoking and Health. Washington, DC; 2010. Available from URL: http://www.ash.org.uk/tax/analysis (Accessed 13 December, 2011).

17. World Health Organization Regional Office for Europe. The European Tobacco Control Report 2007. WHO. Copenhagen, Denmark; 2007. Available from URL: http://www.euro.who.int/en/what-we-publish/abstracts/europeantobacco-control-report-2007 (Accessed 13 December, 2011). 
18. Joossens L, Raw M. 2007. Progress in tobacco control in 30 European countries, 2005 to 2007. Presented at the $4^{\text {th }}$ European Conference Tobacco or Health. Basel, Switzerland; October 2007. Available from URL: http://www.cancer. $\mathrm{dk} / \mathrm{NR} /$ rdonlyres/7976C5B7-0608-429D-9E94-B0E93274E22E/0/Sammenl igningafrygeforebyggelsei30europ\%C3\%A6iskelande.pdf (Accessed 13 December, 2011).

19. Frankenberg G. Between paternalism and voluntarism: tobacco consumption and tobacco control in Germany. In: Unfiltered: conflicts over tobacco policy and public health. Feldman E, Bayer R, editors. Harvard University Press: Cambridge, MA; 2004. pp. 161-90.

20. Hanewinkel R, Isensee B. Five in a row-reactions of smokers to tobacco tax increases: population-based cross-sectional studies in Germany 2001-2006. Tob Control. 2007;16:34-37.

21. American Lung Association. State of Tobacco Control 2010. Am. Lung Assoc. Washington, DC; 2010. Available from URL: http://www. stateoftobaccocontrol.org (Accessed 13 December, 2011).

22. Rabin RL. Tobacco control strategies: past efficacy and future promise. Loyola Los Angeles Law Rev. 2008;41:1721-68.

23. Sanchanta M. Japan considers higher tobacco taxes. Wall Street Journal. 2 November, 2009. Available from URL: http://online.wsj.com/article/ SB125716473476722663.html (Accessed 13 December, 2011).

24. McCurry J. Japanese yen for smoking tested by 33\% cigarette price rise. Guardian. 6 October, 2010. Available from URL: http://www.guardian.co.uk/ world/2010/oct/06/japan-cigarette-tax-increase (Accessed 13 December, 2011).

25. World Health Organization Regional Office for Europe. The European report on tobacco control policy: review implementation of the third action plan for a tobacco-free Europe 1997-2001. WHO. Copenhagen, Denmark; 2002. Available from URL: http://www.euro.who.int/en/what-we-do/health-topics/ disease-prevention/tobacco/publications/2002/european-report-on-tobaccocontrol-policy (Accessed 13 December, 2011).

26. Spinney L. Public smoking bans show signs of success in Europe. Lancet. 2007;369:1507-8.

27. European Public Health Alliance. European smoking bans-evolution of the legislation. EPHA. Brussels, Belgium. Available from URL: http://epha. org/a/1941 (Accessed 13 December, 2011).

28. Phillips L. Commission preparing pan-european smoking ban. EUobserver. Brussels, Belgium; 2010. Available from URL: http://euobserver. com/9/31021 (Accessed 13 December, 2011).

29. American Nonsmokers' Rights Foundation. Summary of $100 \%$ smokefree state laws and population protected by $100 \%$ U.S. smokefree laws. ANRF. Berkeley, CA; 7 October, 2011c. Available from URL: http://www.no-smoke. org/pdf/SummaryUSPopList.pdf (Accessed 13 December, 2011). 
30. Schroeder SA, Warner KE. Don't forget tobacco. N Engl J Med. 2010;363:2014.

31. American Nonsmokers' Rights Foundation. 2011a. Municipalities with smokefree park laws enacted as of April 1, 2011. ANRF. Berkeley, CA; 7 October, 2011a. Available from URL: http://www.no-smoke.org/pdf/ SmokefreeParks.pdf (Accessed 13 December, 2011).

32. Japan Today. Kanagawa adopts anti-smoking ordinance; 1st among 47 prefectures. Japan Today: 25 March, 2009.

33. Brandt, AM. Blow some my way: passive smoking, risk and American culture. In: Ashes to ashes: the history of smoking and health. Lock S, Reynolds L, Tansey EM, editors. Amsterdam: Atlanta, GA; 1998. pp. 164-91.

34. Abt Associates Inc., Hamilton WL, Norton G, Weintraub J. Changing social norms. In: Independent evaluation of the massachusetts tobacco control program, seventh annual report, January 1994 to June 2000. The Massachusettes Department of Public Health. Boston, MA; 2000. pp. 79-94. Available from URL: http://www.mass.gov/eohhs/docs/dph/tobacco-control/ abt-7th-report.pdf (Accessed 13 December, 2011).

35. Bauer UE, Johnson TM, Hopkins RS, Brooks RG. Changes in youth cigarette use and intentions following implementation of a tobacco control program: findings from the Florida youth tobacco survey. JAMA. 2000;284:723-8.

36. California Department of Health Services, Tobacco Control Section. 1998. A model for change: the California experience in tobacco control. Calif. Dep. Health Serv. Sacramento, CA; October 1998. Available from URL: http:// www.cdph.ca.gov/programs/tobacco/Documents/

CTCPmodelforchange1998.pdf (Accessed 13 December, 2011).

37. Gilpin E, Lee L, Pierce J. Changes in population attitudes about where smoking should not be allowed: California versus the rest of the USA. Tob Control. 2004;13:38-44.

38. European Commission Health and Consumer Protection Directorate-General. 2007. Towards a Europe free from tobacco smoke: policy options at the EU level. Green Paper COM2007 27 Final. European Communities. Brussels, Belgium; 2007. Available from URL: http://ec.europa.eu/health/archive/ph_ determinants/life_style/tobacco/documents/gp_smoke_en.pdf (Accessed 13 December, 2011).

39. Chapman S, Freeman B. Markers of the denormalisation of smoking and the tobacco industry. Tob Control. 2008;17:25-31.

40. Feldman EA, Bayer R. Conclusion: lessons from the comparative study of tobacco control. In: Unfiltered: conflicts over tobacco policy and public health. E Feldman E, Bayer R, editors. Harvard University Press: Cambridge, MA; 2004. pp. 292-307.

41. Phelan J, Link B. Controlling disease and creating disparities: a fundamental cause perspective. J Gerontol B. 2005;60B:27-33. 